University of Nebraska - Lincoln

DigitalCommons@University of Nebraska - Lincoln

$12-2007$

\title{
The Future of Leadership Development: The Importance of Identity, Multi-Level Approaches, Self-Leadership, Physical Fitness, Shared Leadership, Networking, Creativity, Emotions, Spirituality and On-Boarding Processes
}

Craig L. Pearce

University of Nebraska - Lincoln, cpearce2@unl.edu

Follow this and additional works at: https://digitalcommons.unl.edu/managementfacpub

Part of the Management Sciences and Quantitative Methods Commons

Pearce, Craig L., "The Future of Leadership Development: The Importance of Identity, Multi-Level Approaches, Self-Leadership, Physical Fitness, Shared Leadership, Networking, Creativity, Emotions, Spirituality and On-Boarding Processes" (2007). Management Department Faculty Publications. 73. https://digitalcommons.unl.edu/managementfacpub/73

This Article is brought to you for free and open access by the Management Department at DigitalCommons@University of Nebraska - Lincoln. It has been accepted for inclusion in Management Department Faculty Publications by an authorized administrator of DigitalCommons@University of Nebraska - Lincoln. 
Published in Human Resource Management Review 17:4 (December 2007; special issue on “The Future of Leadership Development"), pp. 355-359; doi:10.1016/j.hrmr.2007.08.006 Copyright (C) 2007 Elsevier Inc. Used by permission.

Published online September 20, 2007.

\title{
The Future of Leadership Development: The Importance of Identity, Multi-Level Approaches, Self-Leadership, Physical Fitness, Shared Leadership, Networking, Creativity, Emotions, Spirituality and On-Boarding Processes
}

\author{
Craig L. Pearce \\ Peter F. Drucker and Masatoshi Ito School of Management, Claremont Graduate University \\ 1021 North Dartmouth Avenue, Claremont CA 91711, USA
}

\begin{abstract}
Leadership and, consequently, leadership development have taken on far greater import in recent times. As organizations have steadily progressed into the knowledge economy we can no longer rely on simple notions of top-down, command-and-control leadership, based on the idea that workers are merely interchangeable drones. Accordingly, in this special issue you will find seven articles that provide a glimpse over the horizon, so to speak, of leadership development: Together the authors provide a rich research roadmap and a practical set of options for leadership development professionals regarding the next important steps for leadership development, which will carry us well into the 21st Century.
\end{abstract}

Keywords: Leader, Leadership, Development

\section{Introduction}

Leadership development has taken on far greater import in recent years (Day, 2000; McCauley and Van Velsor, 2004; Murphy and Riggio, 2003; Pearce et al., 2006). The reasons for this are manifold and multiplying. Primarily, however, as Peter Drucker identified nearly half a Century ago (Drucker, 1968), we have entered the age of knowledge work. Knowledge work relies on the, necessarily, voluntary contributions of skilled professionals: After all, knowledge workers can withhold their intellectual capital and they can take it with them if and when they choose to leave. Accordingly, we need to rethink the very concept of leadership, and by extension, leadership development, in the age of knowledge work - and that is the very purpose of this special issue on leadership development.

The authors of the seven articles that comprise this special issue tackle a wide breadth of topics that are critical to the future of leadership development. Some approaches are general and some are specific. Some focus on leaders occupying roles, while others focus on leadership as a process. Some document current best practices, while others 
offer agendas for future research. Some focus on lower to mid-hierarchical levels, while others focus on executive levels and yet others identify cross-level issues. Some focus on capacities, capabilities and behaviors while others focus on physical and spiritual dimensions of leadership. What they all have in common, however, is a deep and profound grounding on the historical research foundations of leader and leadership development. Interestingly, in juxtaposition to the deep grounding of the articles that comprise this special issue is the fresh tilling of new, rich and fertile soil for cultivating our next generations of leaders in multi and varied organizational contexts.

Most current leadership development efforts focus on transactional and transformational leadership and focus quite narrowly on individuals who occupy formal leadership positions or are being groomed to occupy such positions eminently. In contrast, in this special issue, the authors argue that the focus of leadership development should be greatly expanded to include a much broader array of behaviors and competencies and should include followers in the process of leadership development (see Pearce, 2004; Pearce and Conger, 2003).

Leadership has long captured the interest of practitioners and academics, as well as the more general public. The scope of this popular interest in leadership - what it is, where it comes from, how we develop and implement itis readily apparent when one walks into any bookstore. Alternatively, simply click on amazon.com and type in the term "leadership" in the book category. I did this on 7 July 2007. It returned 223,726 results. Clearly, there is an insatiable thirst for knowledge about leadership. In our normal, everyday lives we frequently hear arm-chair analyses of peoples' leadership styles - be they corporate leaders, religious leaders, political leaders or civic leaders - as being "blank" types of leaders, further evidencing our perennial preoccupation with leadership, and all that it entails. Indeed, most professionals - be they in the for profit, governmental or social sector - would most likely concur that developing a keen sense of different types of leaders, how they behave, and what they expect, is essential for success, no matter what the organizational context.

Forgetting our formal academic descriptions of leadership, lay descriptions of leadership, at least implicitly, refer to patterns of behavior that seem (perhaps intuitively) consistent or related. For example, an employee's description of a "micro-managing" boss might be intuitively supported by examples of his/her manager's overly precise specification of goals, continual follow-up on progress, ongoing needling, picayune review of performance, and the like. Whether they are intuitive-based on personal experience- or formalized through rigorous research, these clusters or types of related behavior make it easier to size up leaders and make sense of patterns of leadership behavior. Two or more contrasting types of leadership, in turn, form a typology (see Doty \& Glick, 1994) or model of leadership.

Leadership models offer the guiding frameworks that are critical for implementing coherent leadership development efforts. The models guiding leadership development define and, in some cases, limit the leadership development efforts (Cox, Pearce, \& Sims, 2003). Accordingly, the purpose of this special issue is to widen the scope of leadership development beyond today's dominant transactional-transformational leadership model, to include identity, multi-level approaches, self-leadership, physical fitness, shared leadership, networking, creativity, emotions, spirituality and on-boarding processes.

\section{Leadership models and leadership development}

Leadership scholars are often interested in how particular approaches to leadership relate to individual, group, and organizational outcomes. Indeed, most scholarly investigations of leadership assume the form of theories that relate leadership patterns to outcomes such as creativity, effectiveness, satisfaction, and the like. In research settings, then, leadership models identify the cause that the researcher hopes to relate to some type of organizational effect. Accordingly, in leadership development settings, leadership models supply a useful framework that facilitates the understanding of participants' natural leadership proclivities - at least as they relate to the particular model in use-and articulate alternative, perhaps more effective, options. This is why leadership development professionals depend on models to guide their development efforts. As such, leadership theories, and the models on which they rely, are imperative if one is to coordinate a coherent, internally consistent leadership selection, appraisal, training, and development strategy within an organization.

Given the importance of leadership development in both academic research and the practitioner world, it is critical that we articulate leadership models that are as comprehensible, complete and coherent as possible (Cox et al., 2003; Hunt, 1996). As Yukl (1998) so clearly identified, it is imperative that we understand the range of leader behavior patterns and how these patterns affect leaders, followers, and the organizations they enact. Today's leadership development efforts are largely focused on developing two types of leadership: transactional and transformational. 
This duality paints an incomplete developmental picture because it misses many leadership alternatives - alternatives that the authors of this special issue so ably elucidate.

\subsection{The transactional-transformational model}

While the dominant model used in leadership development today is the transactional-transformational model, the subject of much academic leadership research (e.g., Bass and Avolio, 1993; Conger, 1999), a revisionist movement has begun to question whether scholars are missing the potential of a broader range of leadership options by coalescing too narrowly on this two-factor model. Yukl (1989) identified this concern by observing that the transactional-transformational model "is fast becoming a two-factor theory of leadership processes, which is an unwarranted oversimplification of a complex phenomenon" (p. 212). Bass and Avolio (1993) also invited "critics and supporters to join in the effort to shape a theory and model of leadership that capture a broader array of leadership behaviors and attributes than previously studied" (p. 76). This special issue responds to this challenge.

\subsection{The alternative models offered in this special issue}

The vast majority of the articles in this special issue - five of the seven - specify models that identify behaviors or competencies for the focus of leadership development efforts. One article provides a conceptual view on leadership development and the last documents a process model - a veritable "how to" manual - for leadership development in the context of "onboarding" leaders into an organization. Each of these articles is briefly reviewed below.

\subsubsection{Conceptual view}

Day and Harrison (this issue) provide a conceptual view of the leadership development process. Specifically, they argue that leadership development, if it is to be maximally effective, needs to be focused on leaders' sense of identity. Identity, they argue, is the source of meaning from which leaders operate. Accordingly, they argue that focusing on leaders' identities offers the possibility of more profound development than efforts that merely focus on a set of tools/skills to be learned. Their logic is solid. Day and Harrison also provide strong logic for moving development efforts into a multi-level approach, which is consistent with recent articulations of shared leadership theory (e.g. Pearce \& Conger, 2003). Accordingly, it would appear that leadership development efforts would benefit from greater focus on both identity and multi-level approaches.

\subsubsection{Behavior/competency models}

Lovelace, Manz and Alvez (this issue) argue that managing stress has become an acutely important skill for leaders. Accordingly, they focus on self-leadership, shared leadership and a leader's physical fitness as three areas of leadership development that deserve more serious attention, in order to help leaders manage stress. Self-leadership is defined as "incorporat[ing] intrinsic motivation, self-influence skill development and strategic oriented cognitions" (Pearce \& Manz, 2005, p. 133). Clearly, if leaders are not competent self-leaders, their capacity for managing stress and influencing others effectively, is, at best, diminished. Accordingly, self-leadership seems a good candidate for incorporation into leadership development programs. The authors extend their work on self-leadership into the area of physical fitness, specifically as it relates to stress management, and the evidence here is clear and positive regarding the benefits of physical fitness. As such, physical fitness seems to be another good candidate for incorporation into leadership development efforts. Finally, moving to the group level of analysis, Lovelace, et al. describe how shared leadership can provide a more robust leadership system and thereby provide a buffer for the stress that might impact any particular leader. Thus, shared leadership also appears as a useful ingredient for leadership development efforts.

Bartol and Zhang (this issue) identify the importance of networking for leaders. Specifically, they argue that networking skills are critical for capacity acquisition and capital accrual. It is hard to argue against their central proposition - networking has indeed become a critical skill for leaders and it has received scant attention in the leadership development literature. Accordingly, networking skills seem a particularly useful area to concentrate future leadership development efforts, especially when it comes to knowledge work.

Mumford, Hunter, Eubanks, Bedell, and Murphy (this issue) provide a comprehensive review of the interface of leadership and creativity literatures, and they articulate the leadership capacities and capabilities necessary for leading creative efforts. Specifically, they indicate that leaders must have capacities in technical expertise, creative 
thinking skills, social skills, and organizational understanding, in order to be effective at leading creative efforts. Further, they contend that beyond capacities, leaders must have several behavioral and cognitive capabilities - capabilities in defining problems, establishing a context and developing and fielding creative efforts - that are critical to success in creative endeavors. Theirs is, perhaps, the first comprehensive model guiding leadership development efforts in the creative arena. As such, their article deserves serious attention.

Riggio and Lee (this issue) remind us of the importance of emotion and interpersonal relations in leadership. Perhaps we take emotions for granted. Perhaps we have not generally viewed emotions as an arena for leadership development. Whatever the reason, emotions have not received the attention they deserve, when it comes to leadership development. Having said that, there is a growing interest in the area, particularly in leadership practice. As Riggio and Lee point out, however, it is important for leadership development practitioners to base their developmental interventions on sound academic research.

Quatro, Waldman and Galvin (this issue) round out the articles on behavioral/competency models of leadership development. They articulate a holistic/spiritual model of leadership. Their model is provocative. They argue that most leadership development, particularly in business schools, is narrowly focused on analytical and conceptual skills, to the exclusion of the emotional and spiritual side of leadership. Clearly their focus on the emotional side of leadership further buttresses Riggio and Lee's (this issue) arguments, while their focus on the spiritual dimension adds yet another layer to our understanding of leadership development. Beyond the individual components of their model they emphasize the importance of taking a holistic approach to leadership development, advice we would do well to heed.

\subsubsection{Process model}

Conger and Fishel (this issue) provide the final article of this special issue. Their focus is on the process of leadership development. Specifically, they provide a rich, detailed account of the leader "on-boarding" process used at the Bank of America to help individuals' transition into executive roles. On-boarding, as the authors articulate, is an area that has received relatively little attention, in either academic circles or in the practitioner world. As such, their article fills an important void in the literature. Clearly, there are deep insights to be gleaned from their thoughtful analysis.

\section{Conclusion}

As much as we are attempting to push the frontiers of the science of leadership development, leadership is, above all, a performing art with a range of leadership roles that must be filled and enacted in different situations. Oft times a single leader is called upon to fill these many varied roles. Having said that, any single, unitary approach to leadership will be unlikely to effectively address changing leadership demands over time (Cox et al., 2003). To endure successfully, leaders must be prepared to navigate smooth, rapid transitions across a range of leader behaviors in response to situational demands, as well as navigate smooth transitions between leadership and followership (Pearce, 2004; Pearce and Manz, 2005). This is a significant challenge, a challenge shared by leaders and the professionals charged with developing leadership capability. From a development perspective, this challenge requires that development strategy, infrastructure, and curricula be designed to include an array of leadership options, options, at least partially, identified by the authors in this special issue.

Hopefully leadership scholars and leadership development professionals will be able to take from this special issue some alternative models and frameworks and options for building the knowledge, experience, and confidence of aspiring leaders at all levels of organization. Collectively, the authors of the special issue have presented seven alternative views on leadership development in hopes that they will broaden perspectives about what constitutes appropriate leadership development and will encourage leadership development professionals to build a broader range of models into their development efforts.

Conceptually, the seven articles in this special issue build the case for distinguishing between the models presented. Having said that, there is no logical reason leadership development professionals cannot pick-and-choose certain aspects of the models presented here and recombine them, cafeteria style, into programs specifically tailored to their organizational circumstances. Each of the models has compelling advantages and is appropriate for certain circumstances. 
Clearly, each model contributes significantly to the lexicon of leadership development. Just as certainly, considered individually, each model is insufficient to meet the range of challenges that today's leaders are likely to face over time, and across situations. My only hope is that this special issue encourages debate and offers a useful resource guide to those considering a more comprehensive leadership development offering and stimulates thought among those conducting the research necessary for solid, scientifically-based leadership development.

\section{References}

Bass and Avolio, 1993 - B. M. Bass and B. J. Avolio, Transformational leadership: A response to critiques; in: J. G. Hunt, B. R. Baliga, H. P. Dachler, and C. A. Schriesheim, editors, Emerging Leadership Vistas, D. C. Health, Lexington, MA (1993), pp. 29-40.

Conger, 1999 - J. A. Conger, Charismatic and transformational leadership in organizations: An insider's perspective on these developing streams of research. Leadership Quarterly, 10 (1999), pp. 145-170.

Cox et al., 2003 - J. F. Cox, C. L. Pearce and H. P. Sims, Toward a broader agenda for leadership development: Extending the traditional transactional-transformational duality by developing directive, empowering and shared leadership skills; in: S. E. Murphy and R. E. Riggio, editors, The Future of Leadership Development, Lawrence Earlbaum, Mahwah, NJ (2003), pp. 161-180.

Day, 2000 • D. V. Day, Leadership development: A review in context. Leadership Quarterly, 11 (2000), pp. 581-613.

Doty and Glick, 1994 - D. H. Doty and W. H. Glick, Typologies as a unique form of theory building: Toward improved understanding and modeling. Academy of Management Review, 19 (1994), pp. 230-251.

Drucker, 1968 • P. F. Drucker, The Age of Discontinuity, Harper \& Row, New York (1968).

Hunt, 1996 • J. G. Hunt, Leadership: A New Synthesis, Sage Publications, Newbury Park, CA (1996).

McCauley and Van Velsor, 2004 - C. D. McCauley, E. Van Velsor, Editors, The Center for Creative Leadership Handbook of Leadership Development, (2nd ed.), Jossey-Bass, San Francisco (2004).

Murphy and Riggio, 2003 - S. E. Murphy, R. E. Riggio, Editors, The Future of Leadership Development, Lawrence Earlbaum, Mahwah, NJ (2003), pp. 161-180.

Pearce, 2004 - C. L. Pearce, The future of leadership: Combining vertical and shared leadership to transform knowledge work. Academy of Management Executive, 18:1 (2004), pp. 47-57.

Pearce and Conger, 2003 - C. L. Pearce, J. A. Conger, Editors, Shared Leadership: Reframing the Hows and Whys of Leadership, Sage, Thousand Oaks, CA (2003).

Pearce and Manz, 2005 - C. L. Pearce and C. C. Manz, The new silver bullets of leadership: The importance of self and shared leadership in knowledge work. Organizational Dynamics, 34:2 (2005), pp. 130-140.

Pearce et al., 2006 - C. L. Pearce, D. A. Waldman, and C. Csikszentmihalyi, Virtuous leadership: A theoretical model and research agenda. Journal of Management, Spirituality and Religion, 3:1-2 (2006), pp. 60-77.

Yukl, 1989 • G. A. Yukl, Leadership in Organizations, (2th ed.), Prentice Hall, Englewood Cliffs, NJ (1989).

Yukl, 1998 • G. A. Yukl, Leadership in Organizations, (4th ed.), Prentice Hall, Englewood Cliffs, NJ (1998). 